www.czasopisma.marszalek.com.pl/pl/10-15804/npw

\author{
Magdalena Kubarek \\ Uniwersytet Warszawski \\ ORCID: https://orcid.org/0000-0002-6007-7363
}

\title{
Pomiędzy estetyką a polityką. Twórczość Radwy Ashour jako przykład literatury zaangażowanej
}

\section{Between aesthetics and politics. The works of Radwa Ashour as an example of committed literature}

\section{Abstract}

The article discusses committed literature in the contemporary Arab world on the basis of the works of Radwa Ashour (Raḍwà Āšūr, 1946-2014) and its role in shaping social opinion and attitude. Based on the concept of Jacques Rancière, the author analyzes the life and oeuvres of Radwa Ashour in terms of her commitment in the current problems of Egypt and the Arab world, putting forward the thesis that practically from the first to the last works, Ashour consciously uses literature as a sensitive instrument for diagnosis of the condition of Arab society on the one hand, and as an effective tool for shaping attitudes towards specific phenomena on the other hand - often in opposition to the official state discourse. Where direct criticism of government policy due to political censorship and the lack of freedom of speech is not possible, space opens up for an indirect form of discourse offered by literature and art.

Keywords: the contemporary Arab World, Egypt, Palestine, committed literature, Radwa Ashour 


\section{Между эстетикой и политикой. Произведения Радвы Ашур как образец ангажированной литературы}

\section{Аннотация}

В статье, на основе произведений Радвы Ашур (Raḍwà Āšūr, 1946-2014), обсуждается феномен ангажированной литературы в современном арабском мире и ее роль в формировании общественного мнения и поведения. Опираясь на концепцию Жака Рансьера, автор анализирует жизнь и творчество Радвы Ашур с точки зрения ее приверженности актуальным проблемам Египта и арабского мира, выдвигая тезис о том, что практически от первой до последней работы Ашур сознательно использует литературу как чувствительный инструмент для диагностики состояния арабского общества, с одной стороны, и как эффективное средство формирования отношения к конкретным явлениям, с другой стороны - часто в противовес официальному государственному дискурсу. Там, где прямая критика государственной политики из-за политической цензуры и отсутствия свободы слова невозможна, открывается пространство для косвенной формы дискурса, предлагаемой литературой и искусством.

Ключевые слова: современный арабский мир, Египет, Палестина, ангажированная литература, Радва Ашур

\section{Wstęp}

T iteratura pozostaje poza zainteresowaniami politologów i raczej jest uznaJwana za medium popularne jedynie wśród nielicznych, poszukujących estetycznych wrażeń w kontakcie ze słowem pisanym odbiorców. Jednak, jak pokazują niektóre przykłady, pisarz w określonych okolicznościach może stać się równie wpływową postacią jak czołowi politycy i działacze społeczni, a dzieła literackie równie opiniotwórcze jak mass media. Nazwiska pisarzy stają się tym samym ikonami, za którymi stoją określone postawy ideologiczne, kojarzone z daną partią czy ugrupowaniem politycznym, a przynależność do grona czytelników danego pisarza stanowi rodzaj ideowej lub politycznej deklaracji.

Po przyznaniu nagrody Nobla Oldze Tokarczuk przez Polskę przetoczyła się fala dyskusji, rzadko kogo pozostawiając obojętnym. „Tokarczuk jest pisarką jednoznacznie zaangażowaną" - stwierdził Dariusz Kałowicz w programie Trzeci Punkt Widzenia, komentując to wydarzenie. „I wcale 
nie mówię tu o jej wypowiedziach na temat bieżącej polityki partyjnej. Idzie o coś dużo głębszego, o pewne starcie światów, w którym uczestniczymy, i które oglądamy. To jest rzecz zakorzeniona dużo głębiej niż polityka" (Cichocki, Gawin, Karłowicz o Nagrodzie, 2019). Sama autorka zaś określiła siebie następującymi słowami: ,jestem polityczna w najszerszym wymiarze rozumienia polityki, dziś polityczne stało się to, co jemy, z kim żyjemy, jak zwracamy się do innych, czyli podstawowe aspekty naszego życia" (Cichocki, Gawin, Karłowicz o Nagrodzie, 2019).

Jeżeli więc w świecie zachodnim, charakteryzującym się w miarę stabilną sytuacją polityczną i obowiązywaniem demokratycznych standardów, pisarze zajmują stanowisko wobec bieżących problemów, traktując swoje pisarstwo jako ważny głos w toczącej się debacie, należy się więc spodziewać, że ich rola będzie szczególnie ważna w regionach dotkniętych konfliktami i rządzonych przez różnego typu reżimy, w których wolność słowa pozostaje w dużej mierze ograniczona.

Jak zauważa Daniela Finanecu, charakteryzując twórczość amerykańsko-libańskiego pisarza, poety i malarza Ğubrāna Halīla Ğubrāna (Khalila Gibrana, 1883-1931), zaangażowanie literatury nie zawsze musi oznaczać polityczny aktywizm autora, czy też dobitnie sformułowane ideologiczne przesłanie utworu, łatwo identyfikowalne z określoną partią czy opcją polityczną. Polityczność literatury może ujawniać się na poziomie głębokiego zainteresowania twórcy problemami własnego narodu, będącego częścią ogólnoludzkiej wspólnoty oraz poprzez traktowanie twórczości jako narzędzia, które ma służyć ewolucji ludzkości i jej duchowemu rozwojowi (Finanecu, 2011, s. 72).

W niniejszym artykule chciałabym prześledzić życie i twórczość egipskiej pisarki średniego pokolenia, Radwy Ashour ${ }^{1}$ (Raḍwà Āšūr, 1946-2016) pod kątem jej zaangażowania w bieżące problemy Egiptu i świata arabskiego. W swoich rozważaniach opierać się będę na koncepcji Jacquesa Rancière, który twierdził, że pisarz:

1 Ze względu na jej rozpowszechnienie zdecydowałam się stosować w artykule angielską wersję zapisu imienia i nazwiska Radwy Ashour. 
[...] przemierza labirynty świata społecznego i jednostkowego, pochyla się nad pozostałościami, gromadzi ślady, przepisuje znaki, ujawnia tajemnicę cywilizacji i epoki. Jest nie tylko hermeneutą, ale też lekarzem czy symptomatologiem, «zagłębiającym się w ciemną, spodnią stronę lub nieświadomość społeczeństwa, by rozszyfrować przekaz wyryty na ciele zwykłych rzeczy». Jego działalność ma aspekt hermeneutyczny i leczniczy: społeczeństwo staje się świadome własnych sekretnych słabości i zyskuje możliwość ich przezwyciężenia (Franczak, 2017, s. 61).

Radwa Ashour w licznych wywiadach i pracach krytycznych dawała wyraz swoim poglądom na temat zaangażowanej roli pisarza i literatury, a jej twórczość prozatorska stanowi doskonały przykład artystycznej realizacji tych poglądów oraz efektywnego połączenia estetyki i polityki.

\section{Związki estetyki i polityki w świecie arabskim}

Regionem, w którym powiązanie literatury i sztuki z politycznym i społecznym zaangażowaniem ma bardzo długie tradycje, jest świat arabski. Jak wspomina Andreas Pflitsch, w historii literatury arabskiej właściwie nie było okresu „odpolitycznienia”2. Spory toczyły się raczej nie tyle o to, czy literatura powinna być zaangażowana, ale jakimi środkami owo zaangażowanie powinno być „realizowane” (Pannewick, Khalil, 2015, s. 10).

Utylitarna funkcja dzieła, będąca pochodną panującego wśród Arabów przekonania o sprawczej funkcji języka, dominowała w okresie arabskiego odrodzenia w XIX wieku i w pierwszych dziesiątkach XX wieku, kiedy to pionierzy nowej literatury, adaptując zachodnie gatunki (opowiadanie, powieść, dramat), obrali za cel kształtowanie tożsamości narodowej i zagrzewanie do walki z kolonizatorem. W II połowie XX wieku, po powstaniu współczesnych organizmów państwowych, literatura odgrywała rolę propagandową dla istniejących reżimów, firmowała ideologię panarabistyczną lub panislamistyczną, bądź była głosem opozycji. To w latach 50. rozpowszechnił się termin (iltizām), odpowiednik Sartre’owskiego „engagement” czyniąc z autora

${ }^{2}$ Więcej na ten temat literatury zaangażowanej w świecie arabskim zob. Badawi, 1972; Klemm, 1998, 2000; El-Ariss, 2013. 
rzecznika społeczeństw, narodów, partii politycznych lub ideologii ${ }^{3}$. Do świata arabskiego przeniknęły także postulaty francuskich egzystencjalistów, głoszących nakaz moralnego, społecznego i politycznego zaangażowania pisarza w problemy swej epoki, a tych nie brakowało. Literaci zajmowali więc określone stanowisko wobec kryzysów nękających świat arabski oraz angażowali się w sprawy społeczne, stając po stronie wykluczonych, biedoty, czy też kobiet i dzieci (Kubarek, 2016, s. 112). Rok 1967 stanowił koniec ery nacjonalizmu w świecie arabskim oraz zaowocował przedefiniowaniem form literackiego zaangażowania, które zaczęło dla twórców nowego pokolenia oznaczać krytyczne podejście wobec siebie, społeczeństwa, a także historii. W kolejnych dekadach XX wieku pisarze łączyli rozczarowanie życiem politycznym w swoich ojczyznach z nadzieją na lepszą przyszłość, odchodząc od realizmu, poszukiwali nowych środków wyrazu czerpiąc z własnego dziedzictwa kulturowego. Ostatnie przewartościowanie nadeszło wraz z przełomem XX i XXI wieku, gdy kolejnym pokoleniom pisarzy przyszło mierzyć się z nasilającymi się kryzysami politycznymi i ekonomicznymi w świecie arabskim $\mathrm{z}$ jednej strony, $\mathrm{z}$ drugiej strony $\mathrm{z}$ komercjalizacją literatury i agresywnym marketingiem wydawniczym (Pannewick, Khalil, 2015, s. 21).

We wstępie do monografii Commitment and Beyond. Reflections on/of the Political in Arabic Literature since the 1940s., poświęconej politycznemu zaangażowaniu pisarzy arabskojęzycznych, która ukazała się jako pokłosie fali społecznych protestów w krajach arabskich, zwanych Arabską Wiosną, redaktorzy tomu podkreślają zasadność podejmowania rozważań na temat związków polityki i literatury - czy też szerzej pojmowanej sztuki - we współczesnym świecie arabskim następująco:

[p]odobnie jak w przypadku innych wydarzeń zachodzących w przejściowych momentach historii, pytanie o rolę literatury w czasach społecznych przemian i przewrotów jest ponownie poddawane przewartościowaniu, zarówno przez samych pisarzy, jak i w debacie naukowej. U podstaw tego zainteresowania leży kwestia wpływu literatury na rzeczywistość społeczną, a w szerszym znaczeniu relacji między tekstem literackim a rzeczywistością jako taką. W ostatnich latach powiązanie estetyki i polityki stało się przedmiotem żywej dyskusji toczonej

${ }^{3}$ Więcej na ten temat zob. Starkey, 2006, s. 125-126. 
przez artystów, intelektualistów i uczonych w świecie arabskojęzycznym i poza nim (Pannewick, Khalil, 2015, s. 21).

W swoich rozważaniach nad różnymi formami i emanacjami literackiego zaangażowania redaktorzy tomu, w odniesieniu do teorii Thomasa Bedorfa, Kurta Röttgersa czy Rolanda Bleikera, stwierdzają, że polityka w sztuce (a tym samym literaturze) przestała być jedynie przekaźnikiem określonej ideologii za pośrednictwem artystycznego medium, ale stała się rodzajem krytyki, która przede wszystkim obala ustalone porządki polityczne i kulturowe. Ten rodzaj krytyki obejmuje różne formy i strategie, na przykład: dekonstrukcję poszczególnych elementów danego porządku i odsłanianie ukrytych mechanizmów władzy, które go skonstruowały. Z kolei - nawiązując do koncepcji francuskiego filozofa Jacquesa Rancière'a - postulują, że literatura jest tak ważna w świecie arabskim, ponieważ sztuka zapewnia demokratyczną przestrzeń, w której idea lub stan wspólnoty mogą być negocjowane przez jej członków (Pannewick, Khalil, 2015, s. 21).

Radwa Ashour, będąc nie tylko pisarką, ale też akademikiem, także dostrzega uwikłanie literatury arabskiej w realizację celów utylitarnych, wskazując, że proza arabska w XIX i XX wieku rodziła się w kontekście walki o wyzwolenie i związanych z nią kwestii narodowej historii i tożsamości (Ashour, 2000, s. 89). W ten sensie Ashour zdaje się kontynuować tradycje prozy zaangażowanej, łącząc w swoim pisarstwie perspektywę historyczną i współczesną, uniwersalną i egipsko-arabską, jednostkową i narodową.

\section{Życie i twórczość Radwy Ashour}

Radwa Ashour określana jest jako ikona literatury arabskiej i wpływowy głos wśród egipskich i arabskich elit intelektualnych. O jej śmierci, w 2014 roku, pisały nie tylko arabskie, ale też zachodnie dzienniki, w tym „The Guardian”. „Radwa Ashour była potężnym głosem wśród egipskich pisarzy pokolenia powojennego oraz pisarką o wyjątkowej uczciwości i odwadze. Swoim pisarstwem konsekwentnie angażowała się w historię własnego kraju i potrafiła odzwierciedlić ją w sposób pełen pasji” - donosił dziennik (Radwa Ashour obituary..., 2014). „Wyjątkowa pisarka, która „całe życie poświeciła walce o sprawiedliwość i wolność” - informował „Aš-Šarq al-Awsaṭ” (Raḍà “Ǎšūr. 
Ǧisr min 'ițā..., 2014). O randze pisarstwa Ashour może świadczyć fakt, że w 26 maja 2018 w rocznicę urodzin pisarki Google uhonorował ją specjalnym logo „Google Doodle” (Essam, 2018).

Radwa Ashour urodziła się w Kairze, w rodzinie przynależącej do wyższej klasy średniej. Jej ojciec był prawnikiem, zaś dziadek dyplomatą i profesorem literatury. Matka Radwy, choć była córką profesora, poetką i artystką, nie posiadała wyższego wykształcenia. Zajmowała się domem i dziećmi, zgodnie $\mathrm{z}$ obowiązującymi w tamtym okresie normami społecznymi, nad czym pisarka, w swoich późniejszych wypowiedziach, ubolewała. Radwa, w przeciwieństwie do matki, otrzymała staranne wykształcenie. $Z$ rodzinnego domu wyniosła znajomość klasycznej literatury arabskiej oraz zamiłowanie do słowa pisanego. Jako dziecko czytała Nağība Maḥfūẓa, autora powieści obyczajowych i egzystencjalistycznych jedynego arabskiego noblistę w dziedzinie literatury, Ğūrǧiego Zaydāna, autora pierwszego cyklu powieści historycznych, Iḥsāna 'Abd al-Quddūsa, popularnego twórcę romansów obyczajowych oraz Agatę Christie, Conana Doyla i Charlesa Dickensa. W przekładzie na arabski, już na studiach, zapoznała się z twórczością Czechowa i Tołstoja oraz Gabriela García Márqueza, Virginii Wolf i Isabel Allende (Seymour-Jorn, 2005, s. 142).

Nie dziwi więc, że rozpoczynając studia Ashour wybrała specjalizację z komparatystyki. Okres jej nauki uniwersyteckiej przypada na burzliwe lata 60. i 70. XX wieku. Po otrzymaniu tytułu zawodowego magistra kontynuowała naukę na Uniwersytecie Massachusetts w Amherst, gdzie w 1975 roku obroniła doktorat z literatury afroamerykańskiej. Po powrocie do Kairu rozpoczęła pracę jako wykładowczyni na Uniwersytecie 'Ayn Šams, gdzie w 1986 roku została profesorem literatury angielskiej i porównawczej, a od 1990 do 1993 roku pełniła funkcję kierownika Katedry Języka i Literatury Angielskiej. Oprócz działalności naukowej podczas pracy na uczelni Ashour czynnie angażowała się w życie polityczne kraju. Jak pisze „The Guardian”:

[a]ktywizm polityczny był osadzony w jej karierze akademickiej. Gdy prezydent Anwar as-Sadat opowiadał się za normalizacją stosunków z Izraelem, Ashour przyczyniła się do założenia Narodowego Komitetu na Rzecz Zwalczania Syjonizmu na Uniwersytetach Egipskich (Lağna Waṭaniyya li-Muqāwamat aṣ-Ṣahyuniyya fĩ al-Ğāmiāât al-Mișriyya). Później, gdy państwo policyjne Husniego Mubaraka wkroczyło w życie akademickie, pomogła założyć Grupę 9 Marca na 
Rzecz Niezależności Uniwersytetów (Mağmū'at 9 Mārs li-Istiqlāl al-Ğāmiēāt)

(Radwa Ashour obituary..., 2014).

Jej dorobek obejmuje monografie i artykuły naukowe z zakresu literatury arabskiej i amerykańskiej, a także dzieła literackie. Jest autorką autobiografii opisujących poszczególne etapy jej życia: Ar-Rịhla. Ayyam țāliba mișriyya fì Amrīkā (Podróż. Pamiętniki egipskiej studentki w Ameryce, 1983), Atyāf (Widma, 1999), Ațqal min Raḍwà. Maqāṭi min sīra dātiyya (Cięższe niż Radwa. Fragmenty autobiografii, 2013) oraz wydanej pośmiertnie Aș-Sarha (Krzyk, 2014). Ma na swoim koncie także dwa zbiory opowiadań: Ra’aytu an-nahl (Widziałam palmę, 1990), Taqārīr as-sayyid Rā' (Raporty Pana R., 2001) oraz kilka powieści: Hağar dāfi' (Ciepły kamień, 1985) Hadīğa wa-Sawsan (Chadidża i Sawsan, 1989), Sirāğ (Lampa, 1992), Tulātiyyat Garnāta (Trylogia grenadzka, 1994-1995), Qița min Ūrūbā (Część Europy, 2003), Farağ (Radość, 2008), Aț-Tanțūriyya (Kobieta z Tantury, 2010). Została uhonorowana licznymi nagrodami literackimi, z których najważniejsze to the Constantine Cavafy International Prize for Literature (2007 rok) i Literacka Nagroda Sułtana Al-'Uwaysa (Ğā’iza Sulțān Al-'Uways li-ar-Riwāya wa-al-Qișșa, 2011 rok).

\section{Estetyka i polityka w pisarstwie Ashour}

Pisarka należy do pokolenia Egipcjan, którzy - jako młodzi ludzie - najpierw uwierzyli w panarabistyczne idee Nasera, a następnie, gdy arabska potęga w zderzeniu z rzeczywistością okazała się iluzją, dokonywali rozrachunku słabości i opresyjności arabskich reżimów, a ich twórczość stała się papierkiem lakmusowym dla frustracji arabskiego społeczeństwa. Jak ujmuje to Hany Hanafy, jest to pokolenie rewolucji (ǧill aț-tawra), które:

[...] stało się pełnoletnie i zyskało świadomość narodową i polityczną po rewolucji 1952 roku [...], które widziało, jak urzeczywistnia się marzenie o narodowej niepodległości po obaleniu dynastii królewskiej [...] i koniec brytyjskiej okupacji Egiptu. Jest to również pokolenie traumy, które było świadkiem końca egipskich marzeń wraz z klęską w wojnie z Izraelem w 1967 roku, i którego żyjący członkowie są wciąż zakładnikami tej klęski, wzmacnianej i reinkarnowanej 
w zbrojnych wyprawach kolonialnych, jak również we wszystkich przejawach neokolonializmu (Hanafy, 2020, s. 4-5).

Wypowiedzi Radwy Ashour, pojawiające się w licznych wywiadach, świadczą o tym, że z pełną świadomością wykorzystywała ona literaturę jako formę politycznego zaangażowania. W The View from Within (Ghazoul, Harlow, 1994) określiła się jako „Arabka i obywatelka Trzeciego Świata” (cyt. za: Elnahla, 2015). Z kolei w jednym z wywiadów dla „The Guardian” oświadczyła: „[m]oje dziedzictwo w obu przypadkach jest stłamszone (...). Piszę w samoobronie i w obronie niezliczonych innych, z którymi się identyfikuję lub którzy są tacy jak ja” (Elnahla, 2015). Niewątpliwie Ashour traktowała pisanie jako rodzaj zyskiwania podmiotowości, odzyskiwania mocy sprawczej: „[p]iszę, a przestrzeń staje się moja, przestaję być obiektem, na który działa historia, ale staję podmiotem działającym w historii” (Elnahla, 2015). Jak zauważa Caroline Seymour-Jorn dla Ashour pisanie było wyraźnie aktem politycznym i społecznym (Seymour-Jorn, 2005, s. 144).

Analizując twórczość Ashour, możemy wydzielić następujące obszary jej zaangażowania: bieżące wydarzenia i sytuacja polityczna w Egipcie (od rządów As-Sadata, poprzez rządy Husniego Mubaraka i Arabską Wiosnę), sprawa palestyńska (w tym polityka Egiptu wobec Izraela), historia świata arabskiego oraz kwestia równouprawnienia kobiet. Właściwie w każdej z jej powieści - w różnych konfiguracjach i proporcjach - można odnaleźć nawiązania do wszystkich tych zagadnień, aczkolwiek w poszczególnych dziełach zmienia się zarówno optyka, jak i środek ciężkości. Ta kompleksowość dobrze odzwierciedla arabską rzeczywistość i pokazuje, że przy analizowaniu poszczególnych problemów życia politycznego i społecznego w Egipcie należy brać pod uwagę całą sieć wzajemnych powiązań i zależności.

Jak pisze Salmà Bakr, Ashour poświęciła swoje życie Egiptowi, zarówno poprzez działalność polityczną jak i przez swoje powieści, opowiadania i prace przekładowe (Raḍà '̄ěšùr. Ǧisr min 'ițā..., 2014). Do najważniejszych pozycji poruszających na pierwszym planie problematykę egipską zaliczana jest powieść Qiț a min Ūrūbā (Część Europy), która opowiada losy kilku pokoleń rodziny egipskiej na tle burzliwej historii tego kraju w XX wieku. Według Hanyiego Hanafy powieść: 
[...] demontuje oficjalną historię kanonizowaną przez nacjonalistyczne elity i zapisaną w powieściach realistycznych, które utrwalają iluzje narodowej niepodległości i fasadę postępu. Podróż An-Nāẓira [protagonista powieści, MK] w głąb archiwów historii przynosi coś więcej niż samowiedzę i samouzdrowienie: sprzyja etycznemu wglądowi w ludzką sprawczość w historii i możliwość ciągłego przekraczania traumatycznych porażek (Hanafy, 2020, s. 26).

Jednym z motywów, który uobecnia się praktycznie w każdej powieści Ashour, jest kwestia palestyńska. Z tego też powodu Hany Hanafy określa jej twórczość jako archiwum palestyńskiej zagrożonej pamięci (Hanafy, 2020, s. 17). Ashour miała do sprawy palestyńskiej bardzo osobiste podeście ze względu na powiązania rodzinne. W 1970 roku wyszła za Mourida al-Baghutiego (Mūrid al-Bargūtīi, 1944-2021), palestyńskiego poetę i pisarza, któremu rząd egipski po 1967 roku odmówił azylu, skazując go na trzydziestoletnią tułaczkę po różnych krajach w poszukiwaniu bezpiecznej przystani. Powodem odmowy była praca poety w rozgłośni radiowej „Șawt Filasțin”" (Głos Palestyny), będącej w opozycji do oficjalnej polityki ocieplenia stosunków egipsko-izraelskich prezydenta Anwara as-Sadata. Dopiero w 1996 roku Al-Baghuti wrócił do Palestyny i osiadł w Ram Allah. Para doczekała się jednego syna, Tamima al-Baghutiego (ur. 1977, Tamīm al-Barg̉ūtî̀) ${ }^{4}$, który po rodzicach odziedziczył zarówno talent literacki, jak i zamiłowania naukowe (ma na swoim koncie kilka tomów poezji oraz doktoryzował się z nauk politycznych na uniwersytecie w Bostonie) oraz polityczny aktywizm (jego poemat stał się jednym z hymnów rewolucji w 2011 roku). Pod szkłem przykrywającym biurko w swoim gabinecie na Uniwersytecie 'Ayn Šams pisarka trzymała kopię obrazka słynnego syryjskiego rysownika zaangażowanego w sprawę palestyńską Burhāna Kārkūtlīego, przedstawiającą Jerozolimę z podpisem "Jerozolima dla nas i zwycięstwo dla nas” ('Āšūr, 2013, s. 137). Choć nawiązania do tragedii Palestyńczyków i krytyka polityki egipskiej wobec Izraela przewijają się w powieściach Ashour, to jednak dziełem w całości poświęconym Palestynie jest Aț-Tanțūriyya - opowieść o życiu kobiety pochodzącej z wioski Tantura, odzwierciedlająca losy narodu

4 Twórczość Tamima al-Baghutiego omówił Marek M. Dziekan (Dziekan, 2016, s. 153-162). 
Palestyńskiego, który w 1948 roku został zmuszony do opuszczenia swoich domostw i poszukiwania azylu w państwach arabskich, gdzie nie zawsze był mile widzianym gościem.

Historia zajęcia Tantury przez Izraelczyków budzi kontrowersje: niektórzy badacze skłaniają się do wersji, iż doszło do masakry, w której zginęło od 200 do 250 cywilów i jeńców, jednak weterani wojenni zaprzeczają tej wersji wydarzeń (Kamel, 2020,397-410). Ashour wprawdzie nie pozostawia wątpliwości w kwestii przebiegu wydarzeń, jednak Aț-Ṭanțūriyya to nie tyko oskarżenie Izraela o popełnienie zbrodni na narodzie palestyńskim. Powieść opowiada z jednej strony o codziennych zmaganiach, bolączkach, frustracji i niepewności jutra, które warunkowane są sytuacją polityczną i ekonomiczną uchodźców palestyńskich, z drugiej o codziennych radościach, nadziejach i obawach, które mają wymiar uniwersalny. Autorka przedstawia realia życia kolejnych pokoleń na obczyźnie, snując opowieść - o niemożności, ale też i nadziei powrotu, o przeżywanej na nowo traumie porażki - od walki z władzami brytyjskimi, poprzez kolejne wojny arabsko-izraelskie (1948, 1967, 1973), masakry w obozach Szabra i Szatila w Libanie, nieudane intifady. Ustami protagonistki powieści jasno wyraża potrzebę dokumentowania tych wydarzeń, opowiadania historii poszczególnych osób z osobistej, emocjonalnej pespektywy oraz oddania głosu tym grupom, które w oficjalnych czy propagandowych relacjach często są pomijane.

Kolejną mocno zaznaczającą się kwestią w pisarstwie Ashour jest problem sytuacji kobiet w świecie arabskim. Sama Ashour odżegnywała się od przyklejania łatki feministki (Seymour-Jorn, 2005, s. 146), a jej proza daleka jest od nachalnej agitacji. Trudno jednak przeoczyć fakt, że czyniąc kobiety głównymi bohaterkami swoich powieści Ashour starała się dać im należne miejsce w historii i społeczeństwie arabskim. Kwestia kobieca pojawia się w sposób bezpośredni w powieści Sirāğ (Lampy), w której autorka podejmuje kwestie wolności i dyskryminacji. Jej akcja rozgrywa się w XIX wieku na fikcyjnej wyspie u wybrzeży Afryki Wschodniej, zamieszkanej przez ubogich robotników i niewolników pracujących na plantacjach. Protagoniści powieści, młodzi i ubodzy mieszkańcy wyspy, wraz z niewolnikami przygotowują powstanie, aby obalić sprawującego dyktatorskie rządy sułtana. Jak pisze Doaa Embabi, młodzi mężczyźni i kobiety gromadzą wystarczająco dużo odwagi, aby wziąć swój los we własne ręce. Są w stanie przeciwstawić się 
religijno-politycznej retoryce opresji oraz obalić przekonanie władcy, że może on sprawować pełną kontrolę nad czynami, a nawet sumieniami swoich poddanych. Ich nieposłuszeństwo zaczyna się w sferze społecznej i osobistej, a następnie zostaje przekute w bunt w sferze politycznej (Embabi, 2016, s. 14).

Sama autorka określa Sirāğ na poziomie uniwersalnym jako: „opowieść o pokonanym buncie” (Ashour, 2000, s. 90). Jednak i tutaj możemy odnaleźć nawiązania do historii Egiptu oraz kolonializmu, ponieważ fikcja i historia łączą się ze sobą: rewolta niewolników przeciwko sułtanowi, choć przebiega na pierwszym planie, to w tle pojawia się powstanie Urabiego Paszy, którego upadek doprowadził w 1882 de facto do brytyjskiej okupacji Egiptu. Natomiast bombardowanie Aleksandrii w 1882 roku budzi konotacje ze współczesnymi nalotami samolotowymi w Palestynie, Iraku czy Libanie.

Dialektyka przeszłości i teraźniejszości oraz metaforyczny obraz buntu, oporu i straty pojawiają się także w najsłynniejszym dziele Ashour czyli Tulātiyyat Garnātạ (Trylogii Grenadzkiej), uznanej za jedno ze 100 najważniejszych powieści arabskich przez Związek Pisarzy Arabskich. Pierwsza część zatytułowana Garnāṭa (Grenada) zdobyła nagrodę przyznawaną podczas Międzynarodowych Targów Książki w Kairze (Ma'raḍ al-Qāhira ad-Duwalī li-l-Kitāb) jako najlepsza powieść 1994 roku. Rok później, po ukazaniu się kolejnych dwóch części zatytułowanych Maryama (imię jednej z bohaterek) oraz Ar-Rahīl (Wyjazd), trylogia otrzymała pierwszą nagrodę na Pierwszych Targach Książki Arabskich Autorek (Al-Ma'raụ al-Awwal li-Kitāb al-Mar’a al-'Arabiyya) w 1995 roku. Trzyczęściowe kroniki szczegółowo relacjonują stopniowe i celowe rugowanie kultury arabsko-muzułmańskiej w Hiszpanii oraz ukazują różne formy adaptacji i oporu prześladowanej mniejszości na tle historii trzech pokoleń rodziny arabskiej w okresie od 1491 do 1609 roku, czy od upadku Grenady, aż do wypędzenia muzułmanów z Andaluzji.

Wprawdzie dzieło bywa odczytywane głównie w kontekście neokolonializmu i sama autorka przyznała, że inspiracją do napisania powieści była dla niej wojna w Zatoce Perskiej (Guzmán, 2005, s. 129), jednak równie wyraźnie uwidacznia się analogia doświadczeń Palestyńczyków do losu Morysków, którzy podejmując rozpaczliwą próbę stawienia zbrojnego oporu Kastylijczykom nie otrzymali obiecanej pomocy od muzułmanów z Maroka i Imperium Osmańskiego. Ashour, jak pisze María Guzmán, zrywa z romantyczną 
konwencją rozpowszechnioną na Zachodzie, ukazującą Grenadę jako symbol wspaniałej andaluzyjskiej kultury tolerancji. Choć w pewnym stopniu współgra z obecną w kulturze arabskiej tradycją przedstawiania Grenady jako symbolu klęski, to jednak protagoniści powieści nie są ani bohaterami, ani męczennikami (Guzmán, 2005, s. 130). Losy rodziny stanowią metaforę losów pokolenia, ale jednocześnie w sposób plastyczny ukazana jest dynamika i ambiwalentność relacji łączących jej członków oraz destrukcyjny wpływ długotrwałej sytuacji opresyjnej na rodzinę oraz jednostkę.

W powieści poruszony jest także wątek hiszpańskiego podboju Nowego Świata, gdy jeden z bohaterów - jako sługa kastylijskiego duchownego wyjeżdża do Ameryki, gdzie jest światkiem brutalnej kolonizacji rodzimych mieszkańców tych ziem. Paralele pomiędzy opisywanymi w powieści wydarzeniami historycznymi - okupacją Grenady i kolonialnym podbojem, a wydarzeniami współczesnymi - okupacją Palestyny i ingerencją w Iraku, są bardzo czytelne i sama Ashour w wywiadach zachęcała do takiego odczytywania powieści (Seymour-Jorn, 2005-2006, s. 151-152).

Radwa Ashour angażowała się w różne inicjatywy, które miały na celu wywarcie presji na rządach Egiptu, ale uważała też, że pisanie jest rodzajem społecznej i politycznej aktywności, która może mieć realny wpływ na społeczeństwo. Według niej doniosłość roli pisarza polega na tym, iż współuczestniczy on w tworzeniu społecznej i historycznej świadomości. Przekazuje swoją wizję historii warunkowaną własnymi przekonaniami, rzeczywistością, w której żyje, a także stosunkiem do danego okresu historycznego, ówczesnej świadomości i kultury. Dlatego też ta wizja jest wyjątkowa (Seymour-Jorn, 2005-2006, s. 145-146).

Relacja między historią i współczesnością pojawia się w twórczości Ashour w wielu odsłonach. Podobnie jak gros pisarzy egipskich i arabskich, właśnie w przeszłości próbowała odnaleźć klucz to analizy teraźniejszości. Czasem owa analiza ewokuje konieczność rozliczenia, co dobrze ilustruje dialog między An-Nāẓirem, protagonistą powieści Qiț a min Ūrūbā i jego wnuczką Szeherezadą, reprezentującymi różne pokolenia Egipcjan. Szeherezada pytaniem: „Co żeście zrobili, dziadku? Jak doprowadziliście nas do miejsca, w którym jesteśmy?" inicjuje problem odpowiedzialności wcześniejszych pokoleń za świat, w którym przychodzi żyć kolejnym generacjom, i skłania An-Nāzira do autorefleksji: „Dlaczego tak bardzo 
zawiedliśmy; co się stało i kto jest za to odpowiedzialny?" (Cyt. za Hanafy, 2020, s. 6).

Jednocześnie Ashour starała się nie wpaść w pułapkę gloryfikowania świetlanej przeszłości (Ashour, 2000, s. 90), odnajdując - zarówno we współczesnych, jak i historycznych klęskach - wymiar nie tylko narodowy, ale też jednostkowy. Stawiała znak równości pomiędzy wczoraj i dzisiaj, czerpiąc z własnych doświadczeń i posługując się takimi emocjami, takim jak strach czy bezradność, z którymi niezależnie od epoki historycznej mierzą się świadkowie gwałtów i masakr. Jak wspomina:

[d]la mnie Granada była Granadą Morysków, walczących mężczyzn i kobiet, których opór był skazany na porażkę. Była odzwierciedleniem mojego doświadczenia z bombardowaniem Bagdadu, które pociągnęło za sobą bombardowania Synaju w 1967 roku, Bejrutu w 1982 roku i uporczywe bombardowania południowego Libanu. Był to sposób na spenetrowanie moich lęków, bezsilności, a także szans na przetrwanie dzięki oporowi. Może teraźniejszość była zbyt trudna do zniesienia jako teraźniejszość, zbyt paląca. Znalazłam się w przeszłości, która, choć bolesna, nie była tak bolesna jak teraźniejszość. Była to próba oswojenia mojego własnego doświadczenia i opowiedzenia pewnej historii, ponieważ powieściopisarze, jak sądzę, niezależnie od formy, jaką wybiorą, mają do opowiedzenia jakąś historię (Ashour, 2000, s. 91).

Ashour do samej śmierci, pomimo choroby, pozostawała aktywna literacko: przerwała pisanie autobiografii $A s$-Sarha w listopadzie, a zmarła 1 grudnia 2014 r. (datę podaję za wstępem do As-Sarha, 'Ǎšūr, 2015, s. 5; inne źródła podają 30 listopada 2014). Tytuł tego ostatniego, niedokończonego dzieła, pozostaje symptomatyczny i nawiązuje do słynnego obrazu Edvarda Muncha, który uchodzi za metaforę bólu istnienia, samotności i strachu. Wraz z poprzedzającym je Ațal min Raḍwà. Maqāți min sīra dātiyya (Cięższe niż Radwa. Fragmenty autobiografii) stanowi próbę rozliczenia się z wydarzeniami w Egipcie w latach 2011-2014 i ich wpływem na życie jednostek, rodzin i narodu, jak również udziału elit intelektualnych kobiet w tym narodowym zrywie. W autobiograficznych pozycjach nie mogło zabraknąć kwestii palestyńskiej, która niejako wpisana jest w życie polityczne Egiptu. Pojawiają się więc nawiązania do bombardowania strefy Gazy, 
zamiany flagi w ambasadzie Izraela w Kairze, czy haseł propalestyńskich wnoszonych podczas protestów na Placu At-Tahrir. Ashour do tego stopnia przyjmuje na siebie rolę kronikarza, że relacjonując szczegółowo wydarzenia oraz analizując ich tło polityczne, społeczne i ekonomiczne, zdaje się chwilami bardziej uprawiać reportaż niż autobiografię, a za co często przeprasza swoich czytelników ('Awn, 2016, s. 2899-2900), nie jest jednak w stanie ich pominąć, ponieważ zgodnie z tytułem powieści, są ważniejsze od jej życia osobistego - Ațqal min Raḍwà.

\section{Podsumowanie}

Przez całe swoje życie Ashour pozostawała wierna dewizie zaangażowania w bieżące problemy swojej ojczyzny i świata arabskiego, podejmując ważne i palące kwestie w sposób, który dzięki połączeniu fikcji i faktu umożliwiał społeczeństwu specyficzny rodzaj obcowania z traumą.

Lamiyā’'Abd as-Salām wylicza następujące zasługi Ashour: uczestniczyła ona w tworzeniu nowego zasobu wiedzy, nowych alternatyw, wpływała w dużej mierze na ludzką psychikę i posługując się swoją przenikliwością i ostrzem krytyki rzuciła światło na te obszary współczesnej literatury, które pozostawały do tej pory ciemne ('Abd as-Salām, 2018, 40).

Z kolei według Salmy Bakr Ashour była autorką, której prace wywarły ogromny wpływ na następne pokolenia twórców. Jej powieści proklamowały progresywne idee i postulowały zmiany, zarówno w obrębie rzeczywistości, jak i sztuki czy literatury. Należała do szkoły pisarzy zaangażowanych w przekładanie ludzkich obaw na rzeczywistość oraz w zachowanie tożsamość Egipcjan, ale także Arabów (Raḍwà 'Āšūr..., 2014).

Radwa Ashour nie tylko zajmowała krytyczne stanowisko wobec rządów egipskich i sprzeciwiała się proizraelskiej polityce prezydenta As-Sadata, czy też opresyjnej polityce Husniego Mubaraka, mającej na celu ograniczenie wolności słowa, działając w ramach Narodowego Komitetu na Rzecz Zwalczania Syjonizmu na Uniwersytetach Egipskich oraz w Grupie 9 Marca na Rzecz Niezależności Uniwersytetów. Swoje pisarstwo Ashour także traktowała jako rodzaj politycznego zaangażowania, rozumianego jako obowiązek twórczy. W jej powieściach można odnaleźć odniesienie do problemów nurtujących jej rodaków, ale wychodząc poza granice Egiptu, poruszała także takie kwestie 
jak problem palestyński, kolonializm i postkolonializm oraz równouprawnienie kobiet, przedstawiając je zarówno z pespektywy egipsko-arabskiej, jak i uniwersalnej. Niewątpliwie niezwykle ważną rolę pełniła dla Ahour historia, w której pisarka upatrywała klucza do odczytywania teraźniejszości, jak i sposobu na przywrócenie podmiotowości grupom wykluczonym. Tym samym zdawała się realizować postulat Jacquesa Rancière, że pisarz przemierza labirynty świata społecznego i jednostkowego, pochyla się nad pozostałościami, gromadzi ślady, ujawnia tajemnicę cywilizacji i epoki i dzięki temu społeczeństwo staje się świadome własnych sekretnych słabości i zyskuje możliwość ich przezwyciężenia.

Praktycznie od pierwszych do ostatnich dzieł Ashour świadomie wykorzystywała literaturę jako czuły instrument do diagnozy kondycji świata arabskiego, pełniąc rolę „Rancièrowskiego symptomatologa” oraz jako efektywne narzędzie kształtujące postawy wobec określonych zjawisk, konstruowane często w opozycji do oficjalnego dyskursu państwowego.

\section{DR MAGDALENA KUBAREK}

Katedra Arabistyki i Islamistyki

Wydział Orientalistyczny

Uniwersytet Warszawski

ul. Tyniecka 15/17, 00-927 Warszawa

mkubarek@uw.edu.pl

\section{Bibliografia}

'Abd as-Salām, L. )2018). Kātib fī al-Qalb. Aț-Ṭanțūinyya (Raḍ̂à 'Āšūr). W: Ğarma al-wağa! (praca wieloautorska). Al-Qāhira: Dār aš-Šahd li-n-Našr wa-t-Tawzī'.

Ashour, R. (2000). Eyewitness, Scribe and Story Teller: My Experience as a Novelist. The Massachusetts Review, 41(1), 85-92. Pobrane z: http://www.jstor.org/stable/25091630. 'Āšūr, R. (2001). Tulātiyyat Ġarnāța. Al-Qāhira: Dār aš-Šurūq.

'Āšūr, R. (2006). Qiția min Ūrūbā. Al-Qāhira: Dār aš-Šurūq.

'Āšūr, R. (2008). Sirāğ. Al-Qāhira: Dār aš-Šurūq.

'Āšūr, R. (2010). Aț-Ṭanțūriyya. Al-Qāhira: Dār aš-Šurūq.

Āšūr, R. (2013). Ațqal min Raḍwà. Maqāṭi min sīra ḍātiyya. Al-Qāhira: Dār aš-Šurūq. 'Āšūr, R. (2015). As-Sarha. Al-Qāhira: Dār aš-Šurūq. 
'Awn, M. (2016). Atyāf mā ba'da al-ḥadāta fī nașs as-sīra aḍ-d̄āiyya ațqal min Rawḍà fī al-mīzān. Hawliyya Kulliyya al-Luġa al-ÁAabiyya. Ǧāmíat al-Azhar, 20(4), 2865-3003.

Badawi, M.M. (1972). Commitment in Contemporary Arab Literature. Journal of World History, 14, 858-879.

Cichocki, Gawin, Karłowicz o Nagrodzie Nobla dla Olgi Tokarczuk. (2019, 27 października). Pobrano z: https://teologiapolityczna.pl/cichocki-gawin-karlowicz-o -nagrodzie-nobla-dla-olgi-tokarczuk.

Dziekan, M.M. (2016). Tamim al-Barghusi - Arabian Idol. W: I. Kończak, M. Lewicka, M. Widy-Behiesse (red.), Politics and Society in the Islamic World. Łódź: Wydawnictwo Uniwersytetu Łódzkiego.

Elnahla, N.R. (2015). Radwa Ashour (1946-2014): A Literary, Cultural and Political Activist Icon, Echoing in Egypt's Valley. Al Jadid, 19(68). Pobrane z: https://www. aljadid.com/content/radwa-ashour-1946-2014.

Embabi, D.N.E. (2016). The Contribution of Arabic Literature to World Literature: Radwa Ashour's Siraaj a Case in Point. Egyptian Journal of English Language and Literature Studies, 7(1), 83-132. Pobrane z: https://ejels.journals.ekb.eg/article_123250_b0673055d6f816f403e609c5c855561c.pdf.

Essam, A. (2018, 26 maja). Radwa Ashour: A writer of stance. Pobrane z: https://www. egypttoday.com/Article/4/50930/Radwa-Ashour-A-writer-of-stance.

Firanescu, D.R. (2011). Renewing thought from exile: Gibran on the New Era. Synergies - Monde Arabe, 8, 6-80. Pobrane z: https://gerflint.fr/Base/Mondearabe8/rodica_firanescu.pdf.

Franczak, J. (2017). Błądzące słowa. Jacques Rancière i filozofia literatury. Warszawa: IBL PAN.

Ghazoul, F.J., Harlow, B. (red.). (1994). The View from Within. Cairo: The American Univesity in Cairo Press.

Guzmán, M. (2005). Review of Granada: A Novel, by R. 'Ashour, W. Granara, M.R. Menocal. The Arab Studies Journal, 13/14(2/1), 129-132. Pobrane z: http://www.jstor. org/stable/27933939.

Hanafy, H. (2020). Alternative Histories: Renegotiating Colonial Modernity and the Novel Form in Radwa Ashour's A Part of Europe (Qit'a min Urubba, 2003). Journal of Scientific Research in Arts, Language and Literature, 9, p. 1-32. Pobrane z: https:// jssa.journals.ekb.eg/article_136623_02be948b933c61d35a3023b5af805206.pdf.

Klemm, V. (1998). Literarisches Engagement im arabischen Nahen Osten: Konzepte und Debatten. Würzburg: Ergon.

Klemm, V. (2000). Different Notions of Commitment (Iltizām) and Committed Literature (al-adab almultazim) in the Literary Circles of the Mashriq. Arabic and Middle Eastern Literatures, 3(1), 51-62.

Kamel, L. (2010). The Tantura Affair. Oriente Moderno, 90(2), 397-410. Pobrane z: http:// www.jstor.org/stable/23253467.

Kubarek, M. (2016). Między artystyczną ekspresją a moralnym zobowiązaniem. Współczesna literatura muzułmańska. W: M. Tabaczyński, W. Trempała, P. Wenderlich (red.), Kultura zaangażowana. Szkice społeczno-polityczne. Bydgoszcz: Wydawnictwo Uniwersytetu Kazimierza Wielkiego. 
Pannewick, F., Khalil, G. (red.). (2015). Commitment and Beyond. Reflections on/of the Political in Arabic Literature since the 1940s. Wiesbaden: Dr. Ludwig Reichert Verlag. RaḍàĀšūr...Ǧisrmin 'ițāibdā'î̉baynaal-mutahayyilwa-al.-wāqi.(2014,2grudnia).Pobrane z: https://aawsat.com/home/article/234046/\%D8\%B1\%D8\%B6\%D9\%88\%D9\%89-\%D8\%B9\%D8\%A7\%D8\%B4\%D9\%88\%D8\%B1-\%D8\%AC\%D8\%B3\%D8\%B1 - \% D $9 \% 85 \%$ D $9 \% 86$ - \% D $8 \%$ B $9 \%$ D 8 \% B 7 \% D $8 \%$ A 7 \% D $8 \%$ A 1 - \% D 8 \% A 5 \% D $8 \%$ A 8 \% D $8 \%$ A F \% D $8 \%$ A 7 \% D 8 \% B 9 D $9 \% 8$ A -\%D8\%A8\%D9\%8A\%D9\%86-\%D8\%A7\%D9\%84\%D9\%85\%D8\%AA\%D8\%AE\%D9\%8A\%D9\%84-\%D9\%88\%D8\%A7\%D9\%84\%D9\%88\%D8\%A7\%D9\%82\%D 8\%B9\%D9\%8A.

Radwa Ashour obituary. Courag eous Egyptian writer, academic and translator known for her Granada trilogy. (2014, 8 grudnia). Pobrane z: https://www.theguardian.com/ books/2014/dec/08/radwa-ashour.

Seymour-Jorn, C. (2005). Teaching Arabs Women's Literature: Radwa Ashour's Gharnāța. Al-Áabiyya, 38/39, 137-162. Pobrane z: http://www.jstor.org/stable/43192867. Starkey, P. (2006). Modern Arabic Literature. Edinburgh: Edinburgh University Press. 